\title{
THE IMPACT OF INTERNATIONALIZATION AND DIVERSIFICATION ON CONSTRUCTION INDUSTRY PERFORMANCE
}

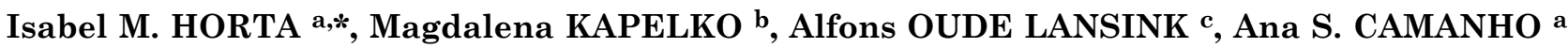 \\ ${ }^{a}$ Department of Industrial Engineering and Management, Faculdade de Engenharia, Universidade do \\ Porto, Portugal \\ ${ }^{b}$ Department of Logistics, Institute of Applied Mathematics, Wroclaw University of Economics, Poland \\ ${ }^{c}$ Business Economics Group, Wageningen University, Netherlands
}

Received 21 November 2014; accepted 5 May 2015

\begin{abstract}
This paper investigates the impact of internationalization and diversification strategies on the financial performance of construction industry companies. The results obtained can guide the design of strategies to pursue company growth and achieve competitive advantage. The evaluation of companies' performance is based on the use of the Data Envelopment Analysis technique to aggregate financial indicators using optimized weights. The impact of internationalization and diversification on company performance is explored using truncated regression, controlling for the effect of contextual factors such as company age, size and time. Data Envelopment Analysis and truncated regression were complemented with bootstrapping to ensure the robustness of the results obtained. The activity of Portuguese and Spanish contractors in the period 2002 to 2011 is used as case study. The empirical results show that internationalization has a positive impact on financial performance, although this effect is only statistically significant for Spanish contractors. Diversification has a nonlinear relationship with performance, benefiting companies with either a small number of core activities or companies with a broad scope of activities.
\end{abstract}

KEYWORDS: Internationalization; Diversification; Construction industry; Data envelopment analysis; Bootstrap truncated regression

\section{INTRODUCTION}

Internationalization and diversification are key issues that are often considered by European construction companies in the design of their strategic plans. The adoption of such strategies became more widespread in recent years due to globalization, which created a more competitive environment in the construction industry (CI).

Internationalization occurs for several reasons. As pointed out by Langford and Rowland (1995), companies internationalize their activity aiming to: i) increase long-term profitability, ii) maintain shareholders return, iii) spread risk over greater operating basis, iv) facilitate growth, v) avoid saturation in domestic markets. Nevertheless, internationalization strategies are also associated to high risk. Various authors in the literature (see for instance Reeb et al. 1998; Jauch, Glueck 1988) reported that expanding business to foreign countries may imply increased competition and management complexity, caused by differences in cultures, labor legislations, business practices, and economic and political systems.

Concerning diversification strategies, the main objectives pursued when engaging in new business activities are: i) to enter industries more profitable than the firm's current business, ii) to exploit economies of scale or scope, iii) to create synergies and cost advantages, iv) to use existing resources and capabilities, vi) to avoid fluctuations or cycles affecting the company core activity. However, diversification could be costly to companies, as it may increase managerial, structural and organizational complexity, cause greater coordination and integration costs, strain top management resources, limit organizational attention, and inhibit companies' ability to respond to major external changes (Chakrabarti et al. 2007). 
Companies need to be aware of the benefits and risks involved in the different strategies to be able to select the best alternatives to enhance performance and gain competitive advantage. In particular, contractors in Portugal and Spain have evolved to more global and competitive markets in recent years, boosting their engagement in diversification and internationalization strategies. In addition, the economic crisis that affected both countries in this period has forced construction companies to redesign their strategies to guarantee financial viability. This paper explores the activity of Portuguese and Spanish contractors in the period 2002 to 2011 to study the relationship between internationalization and diversification strategies and financial performance.

According to EUROSTAT (2015), the Spanish construction sector accounted for approximately $12 \%$ of national GDP and $13 \%$ of total employment in 2007 , but these values decreased in recent years reaching approximately $4 \%$ of national GDP and $6 \%$ of total employment in 2012 .

Similarly, the construction sector in Portugal accounted for about $6 \%$ of national GDP and 9\% of total employment in 2008 , but declined to $4 \%$ of national GDP and 5\% of total employment in 2012. These facts suggest that Spanish contractors were more severely affected by the economic crisis, resulting in a more pronounced decline of the importance of the construction sector in the Spanish economy than in the Portuguese case. During the period 2008-2012 the share of value added from work done abroad through foreign control of construction companies increased from $6 \%$ to $13 \%$ in Spain, and from 1\% to $3 \%$ in Portugal.

An in-depth study of the effect of internationalization and diversification on the performance of construction companies in Iberian countries is of particular interest to support the design of successful business management strategies.

The remainder of this paper is organized as follows. Section 2 presents the conceptual framework of the study, and section 3 describes the methodology. Section 4 presents the empirical part of the paper, including the description of the sample, and the discussion of the results. The last section concludes and suggests future research directions.

\section{CONCEPTUAL FRAMEWORK OF THE STUDY}

The relationship between strategies and company performance has been extensively studied in the literature over the past decades. In particular, in the manufacturing industry the literature has explored in detail the link between internationalization and performance, as well as diversification and performance. However, no consensus has emerged concerning the characterization of these relationships. Palich et al. (2000) and Chakrabarti et al. (2007) provide a literature review on the linkage between diversification and company performance. Assaf et al. (2012) and Hsu and Pereira (2008) review the literature on internationalization and company performance.

In terms of the relationship between internationalization and company performance, the first papers exploring this topic appeared in the 1970s, and mainly highlighted the benefits of internationalization It was argued that companies exposed to competition in international markets are likely to perform better than those only operating at a national level. Later, in the 1990s, researchers acknowledged that internationalization is also subject to risks, which may compromise the success of internationalization strategies. As a consequence, several studies started to explore the benefits and costs of internationalization, and attempted to identify an optimal internationalization level. Due to this shift in the focus of the literature, the models evolved from exploring positive linear relationships (Caves 1971) to also consider negative linear relationships (Ramaswamy 1992), U-shaped relationships (Lu, Beamish 2001), inverted U-shaped relationships (Gomes, Ramaswamy 1999), and Sshaped relationships (Contractor et al. 2002).

In terms of the relationship between diversification and company performance, Gort (1962) was the first to identify a positive linear relationship between both variables, emphasizing the benefits of diversified companies over their counterparts. More recently, other studies hypothesized other types of relationships between diversification and performance. Lubatkin and Chatterjee (1994) and Palich et al. (2000) explored the inverted-U shaped curve and argued that a positive effect occurs as companies move from a single business strategy to a diversification strategy involving related activities. A negative effect occurs as companies move to several unrelated activity areas, such that the benefits of diversification synergies are overshadowed by the costs of running the businesses.

In the construction industry, further research regarding the impact of strategic decisions on company performance is needed (see Isik et al. 2010 and Tan et al. 2012 for a literature review). Only a few studies focused on the influence of 
internationalization and diversification on construction company performance. Yee and Cheah (2006) analyzed the impact of both internationalization and diversification on the performance of large construction companies from North America, Europe and East Asia. The results obtained using Pearson correlation analysis indicate that internationalization is positively associated with liquidity (i.e., current ratio) and negatively correlated with leverage (i.e., book leverage). The relationships for diversification were found to be the opposite. Kim and Reinschmidt (2011, 2012) assessed the impact of diversification on the performance of construction companies in the United States. Using a linear regression analysis, the authors found that diversification contributed significantly to improve business stability but did not affect revenue growth. Jung et al. (2010) analyzed the relationship between entry modes in new markets and company performance (measured as company profit) using a sample of small and medium construction companies in Korea. Using statistical techniques (i.e., T-test, ANOVA and correlation analysis), the authors concluded that companies that expand their operations acting as prime contractors achieved higher profits than subcontractors. In addition, the study revealed that companies with a joint venture in host countries awarded larger contracts than single entities.

None of the studies available in the literature focused on the relationship between strategies and performance in the Iberian CI. This study fulfils this gap by identifying the strategies that are associated with better financial performance in Spain and Portugal. This topic is of practical interest given the difficult economic period that these countries recently faced, which demanded the adoption of effective strategies to increase the competitiveness in global markets. Previous studies have analyzed the financial performance of construction companies in a single country. Those relate to construction companies in Portugal (Horta et al. 2012), Spain (Kapelko et al. 2014; Kapelko, Oude Lansink 2015), or Iran (Wong et al. 2012). This research extends these studies by evaluating the impact of diversification and internationalization strategies on the performance of construction companies in two countries. This study provides insights to guide practitioners in the design of strategies for performance improvement of construction companies. This could be of particular interest also to real estate companies that should be aware of the strategies adopted by construction companies in order to adjust their own management options, as their businesses are deeply connected.

Moreover, previous studies focusing on the relationship between strategies and construction company performance typically use a single accounting measure (e.g. profit or current ratio) to evaluate company performance, and apply statistical methods (e.g. correlation analysis, regression analysis, or hypothesis tests) to identify the nature of relationships. This research enhances these studies by proposing a robust methodology, involving Data Envelopment Analysis (DEA) and truncated regression, to evaluate the impact of diversification and internationalization on the financial performance of construction companies. The methodology proposed has two primary advantages over the traditional approaches. First, it uses a composite indicator, estimated using the DEA technique that evaluates the financial performance of Portuguese and Spanish CI companies. This allows considering simultaneously several key performance indicators to construct a relative measure of performance by comparison to the best practices actually observed in the sector. This is particularly relevant in the assessment of CI companies due to the multidimensional nature of their activity. Second, it uses a truncated regression, specified with a set of control variables (i.e., company age, size, and time), that enables to test U-shaped relationships between strategies and performance. This approach provides more information than traditional models exploring only linear relationships. Although the approach proposed is used in the context of the CI, it could be applied to other sectors including services performance evaluations.

\section{METHODOLOGY}

The methodology used in this study included two primary stages. In the first stage, the financial performance of Portuguese and Spanish construction industry companies is evaluated using a composite indicator, estimated using DEA technique. The composite indicator was then decomposed in two components to investigate in detail the efficiency levels of companies from the two countries. In the second stage, the impact of both diversification and internationalization strategies on the performance of Portuguese and Spanish construction companies is analyzed using truncated regression specified with a set of control variables (i.e., company age, size, and time). Both DEA and truncated regression were complemented with bootstrapping to refine the estimates obtained. 


\subsection{Composite indicator model to assess company performance}

A composite indicator is a mathematical aggregation of a set of sub-indicators for measuring multidimensional concepts that cannot be captured by a single indicator (OECD 2008). Composite indicators have increasingly been accepted as useful tools for performance comparisons, benchmarking, policy analysis and public communication in various fields, such as the economy, environment and society (OECD 2008). There are various methods that can be used to aggregate the indicators in a composite indicator, such as DEA or multicriteria decision analysis. The use of DEA to estimate composite indicators has gained popularity in recent years (see for instance Tsolas 2013; Zanella et al. 2013). A DEA-based composite indicator is obtained through linear programming, and shows each Decision Making Unit (DMU) in its most favorable light. The main feature of using DEA is that each DMU can choose its own set of weights in order to emphasize its strengths.

The use of DEA to aggregate individual indicators was initiated by Lovell (1995) that proposed a DEA model to evaluate countries' performance based on four indicators related to the services provided to citizens. The DEA model used a unitary input for each country, which could be interpreted as a "helmsman" that pursues increased levels of the four service indicators. Later, Cherchye et al. (2004) popularized the use of DEA for the estimation of composite indicators by proposing the use of a simplified linear programming formulation named "benefit of the doubt" weighting. The primary difference between the traditional DEA analysis and the construction of a composite indicator model, as proposed by Cherchye et al. (2004), is that the latter only looks at achievements, without explicitly taking into account the resources used. The rationale for using a DEA model to construct a composite indicator is to aggregate a set of key performance indicators into a single overall measure of performance. The linear programming model proposed by Cherchye et al. (2004) to derive the composite indicator for a DMU $j_{o}$ is shown in (1):

$$
c_{j o}=\max \sum_{r=1}^{s} u_{r} y_{r j o},
$$

subject to

$$
\begin{array}{ll}
\sum_{r=1}^{s} u_{r} y_{r j} \leq 1 & j=1, \ldots, n, \\
u_{r} \geq \epsilon & r=1, \ldots, s .
\end{array}
$$

In model (1), $y_{r j}$ corresponds to the value of the output indicator $r(r=1, \ldots, s)$ in company $j(j=$ $1, \ldots, n)$, with higher values corresponding to better performance. As stated by Cherchye et al. (2004), model (1) is equivalent to the constant returns to scale DEA input oriented model with all indicators considered as outputs and a "dummy input" equals one for all DMUs. The weights $u_{r}(r=1, \ldots, s)$ are the variables of model (1). Model (1) determines the weights $u_{r}$ that give the highest possible score to each DMU assessed, keeping the scores of all other DMUs less than or equal to one when evaluated with similar weights. The composite indicator score $c^{*}{ }_{j o}$ of DMU $j_{o}$ is between 0 (worst) and 1 (benchmark).

To measure the financial performance of construction companies, model (1) was run with a pooled sample of all Portuguese and Spanish contractors in all years whose frontier represents the Iberian best practices. The performance score obtained is called pooled performance. Then, it was explored the differences in the pooled performance of companies from Portugal and Spain. The pooled performance score was decomposed into two components. One component reflects the spread in performance within the country. This component is called within country performance hereafter, and measures the distance of the company to its own country frontier. The within country performance is obtained by running model (1) only with the companies belonging to a particular country (i.e. Portugal or Spain). The other component reflects the gap between the country best practices and the Iberian benchmarks that define the pooled frontier

This component is called country gap hereafter, and measures the distance between the country frontier and the pooled frontier. The country gap corresponds to the ratio between the pooled performance and the within country performance. The decomposition of the pooled performance is shown in (2). This decomposition follows the rationale of the "program efficiency" method, first proposed by Charnes et al. (1981), and popularized by Battese et al. (2004):

Pooled performance $=$ Within country

performance $\times$ Country gap.

To correct the composite indicator estimates for bias, bootstrapping technique was used. Bootstrapping was first introduced by Efron (1979) and it is a resampling method, with replacement, for statistical inference. In particular, it was applied the procedure proposed by Simar and Wilson (1998) that is appropriate to be used with DEA-based performance scores. 


\subsection{Truncated regression to analyze the impact of strategies on company performance}

Truncated regression with bootstrapping is used to evaluate the impact of internationalization and diversification on the performance of construction companies. According to Simar and Wilson (2007) the model that should be estimated to regress DEA performance scores against explanatory variables is a regression model including a truncated term and complemented with bootstrapping. The truncated regression model estimated is shown in (3):

$$
E_{j}=\alpha_{o}+z_{j} \beta+\varepsilon_{j}
$$

Subscript $j$ concerns the $j^{\text {th }}$ company $(j=1, \ldots, n)$; $\mathrm{a}_{o}$ is the constant term; $z_{j}$ represents the factors that may affect company performance, which include diversification and internationalization levels, as well as control variables such as company age, company size and time. $B$ represents the regression coefficients; $\varepsilon$ is the error term with a distribution and a truncation at $\left(1-a_{o}-z_{j}\right)$. Note that $E_{j}$ corresponds to the within country performance score of company $j$, corrected by bootstrapping.

To measure company diversification, one may find different variables in the CI literature. They vary from simple counts of number of businesses (Jin et al. 2013; Yee, Cheah 2006) to measures which assign weights to the relative importance of each business within the company portfolio. Examples of such variables include the entropy measure (Kim, Reinschmidt 2011, 2012) or the concentration ratio (Kang 2006). In this study, it was used a continuous variable representing the number of core businesses to measure diversification. The square of the number of core businesses was also included in the model to test for curvilinearity in the relationship between diversification and performance.

The most common variable used to measure company internationalization is the ratio of international revenue to total revenue (see for instance, Pheng, Hongbin 2003). In this study, as the data available did not allow a more detailed quantification of the level of internationalization, a dichotomous variable was used to distinguish companies with international activity from companies operating only at national level. This approach was also used in a few studies such as Kapelko and Oude Lansink (2013), Delgado et al. (2002), Clerides et al. (1998).

A set of control variables was also included in the truncated regression model to analyze more accurately the effect of diversification and internationalization on company performance. Although the use of control variables is the standard approach in the literature for studies in other sectors (see for instance Hsu, Pereira 2008; Tsao, Lien 2013), previous studies in the CI did not use control variables to moderate the relationship between strategy and performance. The control variables used in our empirical analysis relate to company age, company size, and time. Based on the review of the CI literature (Kale, Arditi 1998; Horta et al. 2012; Kapelko, Oude Lansink 2015), these variables correspond to factors that are likely to have an impact on the performance of construction companies. However, the way they impact company performance remains controversial in the CI literature (see Kale, Arditi 1998, for a review). Company age was included in the model to control for differences in the stage of development of the companies. It was measured as the number of years since company establishment. Company size was included to control for differences in scale size of CI companies, and it was measured as the value of total assets. A dummy variable for each year was also used to account for the time effect.

\section{EMPIRICAL ANALYSIS}

\subsection{Data and sample}

This paper used data from Portuguese and Spanish construction companies. The data was collected from the SABI database, which is a Bureau Van Dijk database that primarily includes financial information of companies from Spain and Portugal. The longitudinal assessment explored an unbalanced sample of 10201 Portuguese contractors and 16198 Spanish contractors from 2002 to 2011. Most of these companies did not have data available for some of the 10 years analyzed, so the total number of observations, corresponding to the operation of a company in a given year, was 28808 for Portugal and 62067 for Spain. Note that all the companies analyzed remained active during the period 2002-2011.

In order to create a homogenous sample, it was analyzed companies belonging to the segment of construction of residential and non-residential buildings (i.e. NACE Rev. 2 code 412). This is the largest subsector of the CI both in Portugal and Spain. In addition, it was excluded from the sample micro companies, according to European Union definition (i.e. companies with fewer than $10 \mathrm{em}$ ployees and operating revenues less than 2 million euros). This approach is in line with existing CI studies, which only analyzed the relationship 
between strategy and performance in small and medium sized companies (e.g. Jung et al. 2010) or in large companies (e.g. Yee, Cheah 2006). These companies are more prone to adopt internationalization and diversification strategies than micro companies. Only the companies with non-negative performance indicators were analyzed due to the limitations of DEA models that could deal with this type of data (see Pastor, Ruiz 2007 for a review).

The key indicators used to describe companies' performance relate to financial aspects. Following previous studies on the CI (Kangari et al. 1992; Curtin 1993; Severson et al. 1994; Pilateris, McCabe 2003), financial indicators are grouped into four main categories, i.e. profitability, liquidity, leverage and activity ratios. In order to assess adequately the financial performance of construction companies, four indicators that represent these categories were selected.

In terms of the indicators' definition, profitability measures the company's ability to generate earnings. The indicator selected to represent profitability was the return on assets. Return on assets is measured as the net profit over total assets, indicating how profitable a company is relative to its total assets. Liquidity measures the company's ability to meet short-term financial obligations. The indicator used to reflect liquidity was the current ratio. Current ratio is measured as the current assets over current liabilities and represents the company's ability to pay its current liabilities (e.g. debts and payables) from its current assets (e.g. cash, inventory, receivables). Leverage provides an indication of company longterm solvency. The indicator selected to cover leverage was the solvency ratio. Solvency is computed as the shareholders' funds over total assets and represents the proportion of the company's total assets financed by equity. Activity measures how well a company uses its resources. The indicator that represents activity is the current asset turnover. Current asset turnover is measured as the net value of sales over current assets, indicating how productive the company is using its assets to generate sales. Table 1 reports the descriptive statistics of the financial variables, and the number of observations included in the assessment for each year and country (Portugal - PT and Spain - ES).

From Table 1 it is possible to verify that Portuguese construction companies have, on average, higher levels of current ratio and solvency, whereas Spanish construction companies perform better in terms of return on assets and current assets turnover.

The sample characteristics in terms of internationalization, diversification and control variables are described in Table 2. Table 2 reports the percentage of companies that exhibited international activity, the average number of core activities for all companies analyzed, the mean company age (measured in years) and the mean company size (measured by total assets in million euros) for each year and country.

Table 2 shows that the proportion of Spanish construction companies that operate internationally is considerably larger than in Portugal. On average, $15 \%$ of the Spanish construction companies in our sample have an international activity, whereas only $2.3 \%$ of the Portuguese companies operated internationally. However, in the last decade, the proportion of Spanish construction companies with international activity reduced, whereas in Portugal this proportion remained stable.

Table 1. Descriptive statistics of performance indicators

\begin{tabular}{|c|c|c|c|c|c|c|c|c|c|c|}
\hline \multirow[t]{2}{*}{ Year } & \multicolumn{2}{|c|}{ No. of observations } & \multicolumn{2}{|c|}{ Return on assets } & \multicolumn{2}{|c|}{ Current ratio } & \multicolumn{2}{|c|}{ Solvency ratio } & \multicolumn{2}{|c|}{ Assets turnover } \\
\hline & $\mathrm{PT}$ & $\mathrm{ES}$ & $\mathrm{PT}$ & ES & $\mathrm{PT}$ & $\mathrm{ES}$ & $\mathrm{PT}$ & $\mathrm{ES}$ & $\mathrm{PT}$ & ES \\
\hline 2002 & 1467 & 5568 & 4.1 & 6.9 & 2.1 & 1.4 & 21.2 & 23.2 & 6.0 & 9.2 \\
\hline 2003 & 2063 & 6237 & 4.3 & 7.2 & 1.9 & 1.4 & 22.2 & 24.0 & 6.0 & 9.0 \\
\hline 2004 & 2492 & 6879 & 4.8 & 7.0 & 2.2 & 1.5 & 23.1 & 23.6 & 6.6 & 8.6 \\
\hline 2005 & 3624 & 7701 & 4.8 & 7.0 & 3.7 & 1.5 & 21.8 & 23.2 & 5.8 & 8.3 \\
\hline 2006 & 3488 & 8562 & 5.6 & 6.8 & 7.9 & 1.6 & 25.6 & 22.3 & 4.5 & 7.6 \\
\hline 2007 & 3676 & 8698 & 6.5 & 6.6 & 5.6 & 1.7 & 26.8 & 23.2 & 6.4 & 7.5 \\
\hline 2008 & 3333 & 6748 & 5.3 & 5.4 & 6.4 & 1.8 & 27.8 & 27.7 & 5.1 & 6.3 \\
\hline 2009 & 3366 & 4947 & 4.8 & 4.7 & 6.1 & 2.0 & 29.3 & 29.9 & 3.9 & 5.1 \\
\hline 2010 & 2898 & 3951 & 4.8 & 4.0 & 6.3 & 2.1 & 31.5 & 31.4 & 3.1 & 4.7 \\
\hline 2011 & 2401 & 2776 & 3.8 & 3.6 & 8.6 & 2.0 & 31.9 & 34.0 & 3.6 & 4.5 \\
\hline Mean & 2881 & 6207 & 5.0 & 6.2 & 5.4 & 1.6 & 26.4 & 25.2 & 5.1 & 7.4 \\
\hline St. Dev. & 749 & 1932 & 5.9 & 5.9 & 42.2 & 1.4 & 16.9 & 17.4 & 13.7 & 8.6 \\
\hline
\end{tabular}


Table 2. Descriptive statistics of the internationalization, diversification and control variables

\begin{tabular}{|c|c|c|c|c|c|c|c|c|}
\hline \multirow[t]{2}{*}{ Year } & \multicolumn{2}{|c|}{$\begin{array}{l}\% \text { international } \\
\text { companies }\end{array}$} & \multicolumn{2}{|c|}{ No. core activities } & \multicolumn{2}{|c|}{ Company age } & \multicolumn{2}{|c|}{ Company size } \\
\hline & $\mathrm{PT}$ & $\mathrm{ES}$ & PT & ES & $\mathrm{PT}$ & ES & $\mathrm{PT}$ & ES \\
\hline 2002 & 2.1 & 19.2 & 1.8 & 1.5 & 21.5 & 21.4 & 2.7 & 5.5 \\
\hline 2003 & 2.3 & 18.5 & 1.8 & 1.5 & 20.2 & 20.6 & 2.8 & 6.0 \\
\hline 2004 & 2.4 & 17.9 & 1.8 & 1.5 & 19.0 & 19.7 & 2.6 & 6.3 \\
\hline 2005 & 2.3 & 17.6 & 1.9 & 1.5 & 20.1 & 18.8 & 3.3 & 7.0 \\
\hline 2006 & 2.2 & 17.2 & 1.8 & 1.5 & 18.1 & 17.9 & 3.0 & 7.7 \\
\hline 2007 & 2.0 & 16.3 & 1.8 & 1.5 & 16.9 & 17.3 & 3.0 & 8.6 \\
\hline 2008 & 2.3 & 13.5 & 1.8 & 1.5 & 16.3 & 17.4 & 3.1 & 9.3 \\
\hline 2009 & 2.3 & 8.2 & 1.8 & 1.5 & 16.2 & 17.8 & 2.9 & 11.9 \\
\hline 2010 & 2.4 & 5.3 & 1.9 & 1.6 & 15.6 & 17.5 & 3.2 & 14.3 \\
\hline 2011 & 2.7 & 4.1 & 1.9 & 1.6 & 14.7 & 17.6 & 3.0 & 19.3 \\
\hline Mean & 2.3 & 15.0 & 1.8 & 1.5 & 17.6 & 18.6 & 3.0 & 8.6 \\
\hline
\end{tabular}

Portuguese construction companies relied more on diversification strategies than Spanish construction companies. Portuguese and Spanish construction companies exhibited, on average, 1.8 and 1.5 core activities, respectively. Note that, on average, $53 \%$ of the Portuguese construction companies in our sample expanded their activity into other areas, whilst only $39 \%$ of Spanish companies adopted diversification strategies. Analyzing only the number of core activities from diversified companies, it is possible to conclude that, on average, Portuguese and Spanish companies have a portfolio of 2.6 and 2.3 activities, respectively. The maximum number of core activities held by Portuguese and Spanish companies was 12 and 7, respectively.

Concerning the description of control variables, the mean company age is 18 and 19 years for Portugal and Spain, respectively, meaning that companies are in a similar stage of development in the two countries. Spanish construction companies operate on a larger scale than their Portuguese counterparts, as suggested by the higher values of total assets.

\subsection{Assessment of company performance}

The first stage of the assessment analyzes the financial performance of Portuguese and Spanish construction companies. In particular, this assessment allowed for exploring the differences in average performance between construction companies in Portugal and Spain (pooled performance). The sources of performance differences are further explored by looking at the spread of performance levels within each country (within country performance), or gaps in performance between the best practices of each country and the Iberian best practices (country gap). Table 3 reports the mean of the bias-corrected performance scores of all companies for Portugal and Spain in each year.

Table 3 shows that there are small differences in the average financial performance of construction companies from Portugal and Spain. This is revealed by the similar average values of the pooled performance for both countries in all years analyzed. Furthermore, Table 3 shows that the pooled performance increased during the period under investigation, meaning that both Portuguese and Spanish companies managed to improve average financial performance in the last decade. Note that the performance scores are within narrow confidence intervals for all companies (i.e., the mean difference between the upper and lower bound of the intervals is approximately 0.005 for the pooled performance, 0.005 and 0.007 for the within country performance in Portugal and Spain, respectively). This provides statistical confidence for the results reported in Table 3 and indicates that the differences between countries are significant.

In addition, the decomposition of the pooled performance shows that Portuguese and Spanish construction companies have different performance profiles. In particular, Spanish construction companies operate closer to their own country frontier, which means that they are more homogeneous in terms of their financial performance. This is revealed by the higher values of the within country performance. However, the high values of the country gap show that the best performing companies in financial terms in the pooled sample are mainly from Portugal. Note that values very close to one imply that Portuguese companies are more often located on the pooled frontier. 
Table 3. Bootstrapped performance scores

\begin{tabular}{|c|c|c|c|c|c|c|}
\hline \multirow[t]{2}{*}{ Year } & \multicolumn{2}{|c|}{ Pooled performance } & \multicolumn{2}{|c|}{ Within country performance } & \multicolumn{2}{|c|}{ Country gap } \\
\hline & $\mathrm{PT}$ & ES & PT & ES & $\mathrm{PT}$ & ES \\
\hline 2002 & 0.28 & 0.32 & 0.28 & 0.42 & 0.98 & 0.75 \\
\hline 2003 & 0.30 & 0.33 & 0.30 & 0.43 & 0.98 & 0.76 \\
\hline 2004 & 0.31 & 0.32 & 0.31 & 0.42 & 0.98 & 0.76 \\
\hline 2005 & 0.29 & 0.32 & 0.29 & 0.41 & 0.98 & 0.76 \\
\hline 2006 & 0.35 & 0.31 & 0.35 & 0.39 & 0.98 & 0.76 \\
\hline 2007 & 0.37 & 0.32 & 0.37 & 0.40 & 0.98 & 0.76 \\
\hline 2008 & 0.37 & 0.36 & 0.37 & 0.42 & 0.98 & 0.82 \\
\hline 2009 & 0.39 & 0.38 & 0.39 & 0.43 & 0.98 & 0.85 \\
\hline 2010 & 0.42 & 0.40 & 0.42 & 0.44 & 0.98 & 0.87 \\
\hline 2011 & 0.42 & 0.43 & 0.42 & 0.47 & 0.98 & 0.88 \\
\hline Mean & 0.35 & 0.34 & 0.35 & 0.42 & 0.98 & 0.78 \\
\hline
\end{tabular}

\subsection{Impact of diversification and internationalization on company performance}

Prior to analyzing the impact of diversification and internationalization on the financial performance of construction companies, multicollinearity between the variables of the bootstrap truncated regression model was tested. One common metric to evaluate multicollinearity is the variance inflation factor (VIF) (see Gujarati 2002). A value of VIF greater than 10 suggests that multicollinearity may cause problems with the estimations. The VIF values for the regressors (independent and control variables) included in the bootstrap truncated regression models ranged between 1.02 and 9.11 , meaning that multicollinearity is not problematic.

To analyze the effect of diversification and internationalization on the financial performance of construction companies, two bootstrap truncated regressions were estimated separately for Portugal and Spain. The bootstrap truncated regression models include the bias-corrected within country performance as dependent variable, diversification and internationalization as independent variables, and company age, size and year as control variables. The total number of observations included in the bootstrap truncated regression model for Portugal was 28808 and for Spain it was 62067, which corresponds to all observations analyzed in all years (see data in Table 1). The bootstrap truncated regression models are statistically significant ( $\mathrm{X}^{2}$ test with $p$-value $\left.<0.0001\right)$. Table 4 reports the results of the estimation of the bootstrap truncated regression models, i.e. the coefficients and the standard errors.

Table 4 shows that diversification has a curvilinear relationship financial performance, as both the first and second order coefficient associated with the number of core activities are statistically significant. For both Portugal and Spain, a U-shaped relationship was found between diversification and financial performance. This means that construction companies with either a very low or a very high number of core activities achieve better financial performance levels, ceteris paribus. This indicates that during the period analyzed, the focus on specific activities

Table 4. Results of the bootstrap truncated regression models

\begin{tabular}{llllll}
\hline Variables & Portugal & & Spain \\
\cline { 2 - 3 } \cline { 5 - 6 } & Coef. & $\begin{array}{l}\text { Std. } \\
\text { Error }\end{array}$ & Coef. & $\begin{array}{l}\text { Std. } \\
\text { Error }\end{array}$ \\
\hline $\begin{array}{l}\text { No. core } \\
\text { activities }\end{array}$ & $-0.039 * *$ & 0.004 & $-0.032 * *$ & 0.004 \\
$\begin{array}{l}\text { No. core activi- } \\
\text { ties squared }\end{array}$ & $0.005 * *$ & 0.001 & $0.007 * *$ & 0.001 \\
International & -0.001 & 0.008 & $0.022 * *$ & 0.002 \\
activity & & & & \\
Constant & $0.266 * *$ & 0.017 & $0.382 * *$ & 0.005 \\
Control variables & & & & \\
Company age & $0.003 * *$ & 0.001 & 0.003 & 0.000 \\
Company size & $-0.825 * *$ & 0.154 & -0.139 & 0.028 \\
2003 & $0.017 * *$ & 0.006 & $0.013 * *$ & 0.004 \\
2004 & $0.034 * *$ & 0.006 & $0.008 *$ & 0.004 \\
2005 & $0.017 * *$ & 0.005 & 0.002 & 0.004 \\
2006 & $0.075 * *$ & 0.006 & $-0.013 * *$ & 0.003 \\
2007 & $0.103 * *$ & 0.007 & -0.004 & 0.003 \\
2008 & $0.107 * *$ & 0.007 & $0.019 * *$ & 0.004 \\
2009 & $0.123 * *$ & 0.008 & $0.031 * *$ & 0.004 \\
2010 & $0.154 * *$ & 0.008 & $0.042 * *$ & 0.004 \\
2011 & $0.156 * *$ & 0.009 & $0.069 * *$ & 0.005 \\
\hline$*$ & & & & \\
\hline
\end{tabular}

* Significant at 5\%; ${ }^{* *}$ Significant at $1 \%$. 
or the expansion into various areas improved company performance more than intermediate diversification strategies, focusing only on a relatively small portfolio of activities. The findings concerning the expansion into various areas are in line with previous research in the CI literature, which concluded that diversified contactors have a better business performance (see, for example, Kim, Reinschmidt 2012).

It is interesting to highlight that most Portuguese construction companies diversified into the real estate sector, by buying and selling real estate, which is an activity unrelated to their core businesses (i.e. construction of residential and nonresidential buildings). In turn, Spanish construction companies diversified mostly to other specialized construction activities and to the development of building projects. These correspond to areas more related with their core business. Despite the distinct diversification strategies followed by Portuguese and Spanish construction companies, the results of the bootstrap truncated regression models suggest that in both countries diversification contributed to improving performance for companies that expanded their business to several core activities.

Results in Table 4 also show that internationalization has a significant and positive impact on the financial performance of Spanish construction companies. In Portugal, there is no evidence that internationalization has a significant impact on the financial performance. Note that the sample of Portuguese companies analyzed includes only a small number of international construction companies, which may explain the absence of a statistically significant effect. In summary, the results suggest that Spanish construction companies benefited from internationalization strategies, although this effect was not found for Portuguese companies. The positive relationship between internationalization and performance found in Spain is consistent with the findings reported in other construction studies (see, for example, Jung et al. 2010).

It is worth mentioning that most Portuguese companies expanded their operations to Angola, whereas most Spanish companies spread their business to Mexico. The positive impact of internationalization on financial performance suggests that expansion to developing countries, with great demand for infrastructure and services, offers great opportunities to the CI.

Concerning the results obtained for the control variables, it is possible to conclude that company age has a positive impact on company perfor- mance, meaning that older companies achieve a better financial performance, ceteris paribus. Company size has a negative effect on company performance, meaning that larger companies tend to have worse financial performance. Finally, the results of the year dummies show that performance varied along the years, and in particular the composite financial performance levels in recent years were better than in 2002 .

\section{CONCLUSIONS}

The relationship between strategic options and company performance has generated a large debate in the literature. Despite its interest for designing successful strategies in highly competitive sectors, only a few studies explored this issue in the construction industry. This paper contributes to the knowledge in this field by analyzing the impact of both internationalization and diversification strategies on the financial performance of construction companies. The empirical application uses firm level data from the construction industry in Portugal and Spain covering the period 2002-2011.

From a methodological point of view, a composite indicator model was used to evaluate the financial performance of construction companies. It involved the use of DEA to estimate the weights to be used in the aggregation of financial indicators. This innovative perspective allows considering simultaneously several indicators to evaluate financial performance, avoiding biased perspectives that may result from only looking at a single indicator (e.g., profitability). The effect of internationalization and diversification on financial performance of companies was explored using a bootstrap truncated regression model considering a set of control variables (i.e., company age, company size and time).

From the empirical results, it is possible to conclude that Portuguese and Spanish contractors achieved, on average, similar levels of financial performance, despite having different profiles. Typically, Spanish construction firms operate closer to their own country frontier, indicating that they are more homogeneous in terms of financial performance. Portuguese construction companies are more often located on the frontier of the Iberian best practices, meaning that the best practices in the pooled sample correspond to Portuguese companies. However, other Portuguese construction companies lag considerably behind their peers. 
Furthermore, our results show that internationalization has a positive impact on financial performance, although its effect was only statistically significant for Spanish companies. Based on these results, construction managers should adopt internationalization strategies in order to improve financial performance. As the majority of Spanish companies with successful internationalization strategies expanded their activity to Mexico, it is possible to conclude that cultural and institutional similarities may have a positive contribution in the internationalization process. Concerning the case of Portugal, as the internationalization strategies did not lead to substantial improvements in the financial results, the promotion of support programs for internationalization by administrative authorities could be a way to foster the achievement of better results. This could include the establishment of protocols to facilitate the operation of national companies in foreign countries.

Diversification has a U-shaped relationship with financial performance, meaning that only specialized companies or those with a relatively large number of core activities managed to achieve the highest levels of financial performance. This result was verified both for Portuguese and Spanish construction companies. This suggests that managers should either downscale the operations into few specific building or construction tasks (e.g., by acting in the sector as a subcontractor), or considerably expand the activity to several areas. In this case, diversification can allow companies to act in the market as general contractors, improving negotiation power and benefiting from scale economies. For instance, the expansion of business into the real estate sector can be a good option for construction companies due to the increased fiscal incentives that are stimulating the rental market in Portugal and Spain.

Future research could attempt to analyze the impact of strategies on the performance of different functional areas, such as commercial or operational. More robust routines of data collection, promoted by regulatory authorities or construction industry associations, may also contribute to the reliability of results obtained in future studies. Efforts of standardization in data collection may also allow cross-country analysis, involving several countries or worldwide regions. Finally, qualitative research could analyze in detail the benchmark companies in order to identify the best practices in areas such as the entry mode in the new market/country, rate of expansion, or leadership. Such analysis can help designing and implementing successful internationalization and diversification strategies.

\section{ACKNOWLEDGMENTS}

The funding of this research through the scholarship SFRH/BPD/86294/2012 from the Portuguese Foundation of Science and Technology (FCT) is gratefully acknowledged by the first author. The calculations of bootstrapping have been carried out in the Wroclaw Centre for Networking and Supercomputing (www.wcss.wroc.pl), grant no. 286.

\section{REFERENCES}

Assaf, A. G.; Josiassen, A.; Ratchford, B. T.; Barros, C. P. 2012. Internationalization and performance of retail firms: a Bayesian dynamic model, Journal of Retailing 88(2): 191-205. http://dx.doi.org/10.1016/j. jretai.2011.11.005

Battese, G. E.; Rao, D. S. P.; O'Donnell, C. J. 2004. A metafrontier production function for estimation of technical effciencies and technology gaps for firms operating under different technologies, Journal of Productivity Analysis 21(1): 91-103. http://dx.doi. org/10.1023/B:PROD.0000012454.06094.29

Caves, R. E. 1971. International corporations: the industrial economics of foreign investment, Economica 38(149): 1-27. http://dx.doi.org/10.2307/2551748

Chakrabarti, A.; Singh, K.; Mahmood, I. 2007. Diversification and performance: evidence from East Asian firms, Strategic Management Journal 28(2): 101-120. http://dx.doi.org/10.1002/smj.572

Charnes, A.; Cooper, W. W.; Rhodes, E. 1981. Evaluating program and managerial effciency: an application of data envelopment analysis to program follow through, Management Science 27: 668-697. http:// dx.doi.org/10.1287/mnsc.27.6.668

Cherchye, L.; Moesen, W.; Puyenbroeck, T. V. 2004. Legitimately diverse, yet comparable: on synthesizing social inclusion performance in the EU, Journal of Common Market Studies 42(5): 919-955. http:// dx.doi.org/10.1111/j.0021-9886.2004.00535.x

Clerides, S. K.; Lach, S.; Tybout, J. R. 1998. Is learning by exporting important? Micro-dynamic evidence from Colombia, Mexico, and Morocco, Quarterly Journal of Economics 113(3): 903-947. http://dx.doi. org/10.1162/003355398555784

Contractor, F. J.; Kundu, S. K.; Hsu, C. -C. 2002. A three-stage theory of international expansion: the link between multinationality and performance in the service sector, Journal of International Business Studies 34(1): 5-18. http://dx.doi.org/10.1057/ palgrave.jibs. 8400003

Curtin, J. J. 1993. The basic bond book. Associated General Contractors of America and National Association of Surety Bond Producers, Washington.

Delgado, M. A.; Farinas, J. C.; Ruano, S. 2002. Firm productivity and export markets: a non-parametric 
approach, Journal of International Economics 57(2): 397-422. http://dx.doi.org/10.1016/S00221996(01)00154-4

Efron, B. 1979. Bootstrap methods: another look at the jackknife, The Annals of Statistics 7(1): 1-26. http:// dx.doi.org/10.1214/aos/1176344552

EUROSTAT. 2015. Available at: http://epp.eurostat. ec.europa.eu

Gomes, L.; Ramaswamy, K. 1999. An empirical examination of the form of the relationship between multinationality and performance. Journal of International Business Studies 30(1): 173-187. http://dx.doi. org/10.1057/palgrave.jibs.8490065

Gort, M. 1962. Diversification and integration in American industry. Princeton: Princeton University Press.

Gujarati, D. 2002. Basic econometrics. $5^{\text {th }}$ ed. New York: McGraw-Hill/Irwin.

Horta, I. M.; Camanho, A. S.; Moreira da Costa, J. 2012. Performance assessment of construction companies: a study of factors promoting financial soundness and innovation in the industry, International Journal of Production Economics 137(1): 84-93. http://dx.doi. org/10.1016/j.ijpe.2012.01.015

Hsu, C. C.; Pereira, A. 2008. Internationalization and performance: the moderating effects of organizational learning, Omega 36(2): 188-205. http://dx.doi. org/10.1016/j.omega.2006.06.004

Isik, Z.; Arditi, D.; Dikmen, I.; Birgonul, M. T. 2010. Impact of resources and strategies on construction company performance, Journal of Management in Engineering 26(1): 9-18. http://dx.doi.org/10.1061/ (ASCE)0742-597X(2010)26:1(9)

Jauch, L. R.; Glueck, W. F. 1988. Business policy and strategic management. New York: McGraw-Hill.

Jin, Z.; Deng, F.; Li, H.; Skitmore, M. 2013. Practical framework for measuring performance of international construction firms, Journal of Construction Engineering and Management 139(9): 1154-1167. http:// dx.doi.org/10.1061/(ASCE)CO.1943-7862.0000718

Jung, W.; Han, S.; Park, H.; Kim, D. 2010. Empirical assessment of internationalization strategies for small and medium construction companies, Journal of Construction Engineering and Management 136(12): 1306-1316. http://dx.doi.org/10.1061/(ASCE) CO.1943-7862.0000237

Kale, S.; Arditi, D. 1998. Business failures: liabilities of newness, adolescence, and smallness, Journal of Construction Engineering and Management 124(6): 458-464. http://dx.doi.org/10.1061/(ASCE)07339364(1998)124:6(458)

Kang, J. 2006. Strategic analysis of large local construction companies in China: PhD Thesis. Nanyang Technological University, Singapore.

Kangari, R.; Farid, F.; Elgharib, H. 1992. Financial performance analysis for construction industry, Journal of Construction Engineering and Management 118(2): 349-361. http://dx.doi.org/10.1061/(ASCE)07339364(1992)118:2(349)

Kapelko, M.; Oude Lansink, A. 2013. Technical effciency of the Spanish dairy processing industry: do size and exporting matter?, in A. B. Mendes, E. L. D. G. S. d.
Silva, J. M. A. Santos (Eds.). Effciency measures in the agricultural sector. Springer, 93-106.

Kapelko, M.; Oude Lansink, A. 2015. Technical effciency and its determinants in the Spanish construction sector pre- and post- financial crisis, International Journal of Strategic Property Management (19): 96109. http://dx.doi.org/10.3846/1648715X.2014.973924

Kapelko, M.; Oude Lansink, A.; Stefanou, S. E. 2014. Assessing dynamic ineffciency of the Spanish construction sector pre- and post-financial crisis, European Journal of Operational Research 237(1): 349-357. http://dx.doi.org/10.1016/j.ejor.2014.01.047

Kim, H. J.; Reinschmidt, K. 2012. Market structure and organizational performance of construction organizations, Journal of Management in Engineering 28(2): 212-220. http://dx.doi.org/10.1061/(ASCE)ME.19435479.0000082

Kim, H. J.; Reinschmidt, K. F. 2011. Diversification by the largest US contractors, Canadian Journal of Civil Engineering 38(7): 800-810. http://dx.doi. org/10.1139/111-056

Langford, D. A.; Rowland, V. R. 1995. Managing overseas construction contracting. London: Thomas Telford Publications. http://dx.doi.org/10.1680/mocc.20290

Lovell, C. A. K. 1995. Measuring the macroeconomic performance of the Taiwanese economy, International Journal of Production Economics 39(1-2): 165-178. http://dx.doi.org/10.1016/0925-5273(94)00067-K

Lu, J. W.; Beamish, P. W. 2001. The internationalization and performance of SMEs, Strategic Management Journal 22(6-7): 565-586.

Lubatkin, M.; Chatterjee, S. 1994. Extending modern portfolio theory into the domain of corporate diversification: does it apply?, Academy of Management Journal 37(1): 109-136. http://dx.doi. org/10.2307/256772

OECD. 2008. Handbook on constructing composite indicators: methodology and user guide. OECD publishing edition.

Palich, L. E.; Cardinal, L. B.; Miller, C. C. 2000. Curvilinearity in the diversification performance linkage: an examination of over three decades of research, Strategic Management Journal 21(2): 155-174. http://dx.doi.org/10.1002/(SICI)10970266(200002)21:2<155::AID-SMJ82>3.0.CO;2-2

Pastor, J. T.; Ruiz, J. L. 2007. Variables with negative values in DEA, in J. Zhu, W. D. Cook (Eds.). Modeling data irregularities and structural complexities in data envelopment analysis. Springer, 63-84.

Pheng, L. S.; Hongbin, J. 2003. Internationalization of Chinese construction enterprises, Journal of Construction Engineering and Management 129(6): 589-598. http://dx.doi.org/10.1061/(ASCE)07339364(2003)129:6(589)

Pilateris, P.; McCabe, B. 2003. Contractor financial evaluation model (CFEM), Canadian Journal of Civil Engineering 30(3): 487-499. http://dx.doi. org/10.1139/102-098

Ramaswamy, K. 1992. Multinationality and performance: a synthesis and redirection, Advances in International Comparative Management 7(1): 241-267. 
Reeb, D. M.; Kwok, C. C. Y.; Baek, H. Y. 1998. Systematic risk of the multinational corporation, Journal of International Business Studies 29(2): 263-279. http:// dx.doi.org/10.1057/palgrave.jibs.8490036

Severson, G.; Russell, J. S.; Jaselskis, E. J. 1994. Predicting construction contract surety bond claims using contractor financial data, Journal of Construction Engineering and Management 120(2): 405-420. http://dx.doi.org/10.1061/(ASCE)07339364(1994)120:2(405)

Simar, L.; Wilson, P. 1998. Sensitivity analysis of effciency scores: how to bootstrap in nonparametric frontier models, Management Science 44(1): 49-61. http://dx.doi.org/10.1287/mnsc.44.1.49

Simar, L.; Wilson, P. 2007. Estimation and inference in two-stage, semi-parametric models of production processes, Journal of Econometrics 136(1): 31-64. http:// dx.doi.org/10.1016/j.jeconom.2005.07.009

Tan, Y.; Shen, L.; Langston, C. 2012. Competition environment, strategy, and performance in the Hong Kong construction industry, Journal of Construction Engineering and Management 138(3): 352-360. http:// dx.doi.org/10.1061/(ASCE)CO.1943-7862.0000407
Tsao, S. M.; Lien, W. H. 2013. Family management and internationalization: the impact on firm performance and innovation, Management International Review 53(2): 189-213. http://dx.doi.org/10.1007/s11575-0110125-9

Tsolas, I. E. 2013. Construction project monitoring by means of RAM-based composite indicators, Journal of the Operational Research Society 64(8): 1291-1297. http://dx.doi.org/10.1057/jors.2012.147

Wong, W. P.; Gholipour, H. F.; Bazrafshan, E. 2012. How effcient are real estate and construction companies in Iran's close economy?, International Journal of Strategic Property Management 16(4): 392-413. http://dx.doi.org/10.3846/1648715X.2012.740513

Yee, C. Y.; Cheah, C. Y. J. 2006. Interactions between business and financial strategies of large engineering and construction firms, Journal of Management in Engineering 22(3): 148-155. http://dx.doi.org/10.1061/ (ASCE)0742-597X(2006)22:3(148)

Zanella, A.; Camanho, A. S.; Dias, T. G. 2013. Benchmarking countries' environmental performance, Journal of the Operational Research Society 64(3): 426-438. http://dx.doi.org/10.1057/jors.2012.62 